\title{
Trade Complementarity and the Balance of Payments Constraint Hypothesis: A New Free Trade Agreement between Mexico and South Korea
}

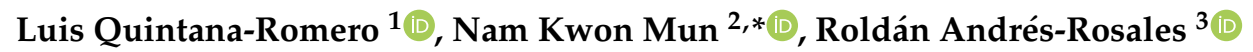 \\ and José Álvarez-García 4 (D) \\ 1 Department of Economics, Facultad de Estudios Superiores Acatlán UNAM, \\ Estado de Mexico 53150, Mexico; luquinta@acatlan.unam.mx \\ 2 Department of Latin American Studies, GSIAS, Hankuk University of Foreign Studies, Seoul 130-791, Korea \\ 3 Department of Administration, Facultad de Estudios Superiores Cuatitlán UNAM, \\ Estado de Mexico 54714, Mexico; roldandres@yahoo.com.mx \\ 4 Financial Economy and Accounting Department, Faculty of Business, Finance and Tourism, \\ University of Extremadura, 10071 Cáceres, Spain; pepealvarez@unex.es \\ * Correspondence: namkwon@hotmail.com
}

Received: 25 August 2020; Accepted: 25 September 2020; Published: 4 October 2020

\begin{abstract}
Market diversification is one of the keys to success in the new era of world trade. Highly competitive countries have accomplished positive and sustained growth rates by not depending on a single market for their exports and imports. In Mexico, on the contrary, $80 \%$ of exports and $45 \%$ of imports concentrate in the United States. The South Korean market represents an opportunity for the Mexican economy, as the relationship between the two countries has strengthened in recent decades. This opportunity would promote greater economic growth for both countries if they reached a Free Trade Agreement, as we show in this work. The aim of this research is to assess the complementarity between these countries and estimate their external long-term equilibrium using the Thirlwall trade restriction model. Results confirm the existence of trade complementarity between the two economies and show that these are able to achieve long-term equilibrium in the external sector. Additionally, the Mexican economy would not face balance of payment constraints for growth when trading with South Korea, as it currently does with the United States.
\end{abstract}

Keywords: international trade; exports; imports; Thirlwall law; cointegration; economic growth; trade complementarity; free trade agreement; South Korea; Mexico

\section{Introduction}

Trade protection in the Mexican manufacturing sector allowed national companies to face a captive domestic market, until the mid-1980s when economic policy changed direction. Protection warranted higher profit margins for the business owners and created high levels of inefficiency, which were paid for by Mexican consumers, who had to face higher prices that negatively affected their well-being [1]. In this context, trade liberalisation was advocated and international trade was considered a factor that would benefit Mexican consumers, since goods would become cheaper as a result of bolder competition in the national market. More competitive companies would make technology and knowledge transfer possible, increasing productivity in local markets and lowering production costs, thereby gaining national and international competitive advantage.

The trade liberalisation promoted in Mexico since the mid-1980s, with its entry into the General Agreement on Tariffs and Trade (GATT) — the World Trade Organization (WTO) predecessor-and in the 1990s with the negotiation and implementation of the North American Free Trade Agreement 
(NAFTA), meant that a greater export orientation would favour both economic and productivity growth in the Mexican economy [2]. However, liberalisation was not able to meet the expectations that its promoters expected: although it turned Mexico into one of the main world exporters, it did not imply greater economic dynamism in the country [3]. Despite the growth of manufacturing exports, the Mexican economy has grown less than other countries that also carried out processes of opening their economies, such as South Korea [4].

The relationship between economic growth and trade openness has been extensively studied. Although a large part of the literature seems confirm the positive impact of trade on growth [5-21], there is no consensus as to whether greater trade openness definitely stimulates economic growth. Studies such as those by Vamvakidis [22], Afzal and Hussain [23] and Ulaşan [24] do not find support for the hypothesis of growth driven by trade, while Fenira [25] finds a weak relationship and others have found an negative impact [26].

In particular, critical approaches have pointed out that trade agreements are a form of protectionism against non-member countries [27]. From the pioneering work on the subject, the theory of customs unions warned that trade agreements could have contradictory effects of trade creation and trade diversion, and that the net result for the growth of participating countries would depend on which effect was dominant $[28,29]$. It has even been argued that it is impossible to determine beforehand whether a trade agreement will have positive effects for its members [30] and ex-ante measurement models have been questioned for underestimating final impacts [31].

A more modern perspective has placed trade agreements as a way to take advantage of economies of scale [32]. In particular, Krugman has indicated that, in a framework of imperfect competition, as trade agreements increase, the trade-creation effect becomes more positive [33], which would somehow justify that countries were seeking to increase their amount of trade agreements. However, it has also been argued that these effects are not necessarily automatic, that they largely depend on the institutional framework under which partners must operate, and that institutional inefficiencies are reflected in higher transaction costs $[34,35]$.

The positive impact of trade openness on growth is based on the hypothesis of the natural trade partner, which assumes that trade creation processes depend on the existing trade volume prior to the trade agreement and on the physical distance between the countries [29,36,37]. However, complementary trade structures have proved to place countries in a position to exploit the mutual benefits of a trade agreement, even when they are not neighbours or have an established trade relationship [38].

The discussion on the growth effects of trade agreements, as previously seen, depends largely on the factors that operate on the creation and diversion of trade. In addition to the institutional restrictions above mentioned, Thirlwall [39] has pointed out that there are also balance of payments constraints, which could influence the trade-creation effect between the members of a trade agreement. The available evidence has provided elements to consider that, after a process of trade opening, restrictions in the balance of payments may condition economic growth below the economic potential of the countries in the agreement [39-45]. The balance of payments constraints manifest in a current account deficit, which limits growth as fragility occurs in the financial, exchange and fiscal spheres [3].

The balance of payments constraint hypothesis has been used in the Mexican case primarily to evaluate the external restriction coming from its trade with the United States. The consensus in these studies indicates that the trade liberalisation policy implemented by Mexico since the 1980s has increased import elasticity, which, in turn, has constrained growth [46,47], and has overall worsened macroeconomic performance [48]. The high concentration of Mexican trade with its northern neighbour, as well as its high vulnerability to external cycles, make it necessary to ponder the alternatives for greater trade diversification. This article seeks to add to the discussion on the external restriction hypothesis, by delving into Mexico's commercial relationship with an economy other than the United States, namely South Korea, and at the same time contribute to the evaluation of trade diversification opportunities with the potential of increasing Mexico's economic resilience against external shocks. 
In this paper, we turn to a modern version of the natural trading partner hypothesis, under which there should be greater complementarity rather than commercial substitutability among trading partners [49], and we extend it by establishing that, in addition to complementarity, a process of long-term trade equilibrium must occur between trading partners, with no growth restrictions coming from the balance of payments.

Under the proposition that Mexico would potentially benefit from a trade agreement with South Korea, the aim this research is to evaluate the trade complementarity between the two countries and assess their long-term equilibrium. To test the hypothesis that a free trade agreement between Mexico and South Korea would benefit both economies, we compute trade complementarity indices and estimate the Thirwall model of trade restriction, to determine the long-term equilibrium in the commercial relationship between the two countries. In particular, the Korean case offers important lessons on how international insertion could be carried out, in order to generate virtuous cycles of growth of the type considered by Thirlwall [50] and Kaldor [51].

In what follows, Section 2 will discuss the commercial relationship between Mexico and South Korea, the importance of trade agreements and their limits for long-term growth in recent years. Section 3 will present the methodology for the selected trade complementarity indicators and for the Thirlwall model, as well as results of their estimation. Finally, we will discuss our work and draw the most relevant conclusions in Section 4. The database used for the model can be found in Appendix A (Tables A1-A3) at the end of the document.

\section{Mexico's and South Korea's Trade Relationship}

The global economic crisis that started in August 2007 in the United States had serious repercussions for Mexico. The depth—and the extent—of the crisis has been the most serious that the country has experienced in its modern history: the drop by more than six percentage points in Mexican GDP in 2009 is unmatched by almost any country in the world.

Retrospective analysis supports the claim that-to a large extent-the strong effects of the crisis in Mexico can be attributed to its synchronisation with the American economic cycle [52]. Mexico's economic vulnerability could be explained by several factors; however, without a doubt, one of the most relevant has to do with the commercial dependence of Mexican exports to the US market. Since the beginning of Donald Trump's presidency in January 2017, an element of uncertainty has been felt in the economic relationship between these countries, especially since the American president has accused Mexico of stealing jobs from his country and dispatching "criminals" to the US, in addition to constantly threatening with unilateral tariffs. The current crisis generated by the COVID-19 pandemic has once again shown the fragility of the Mexican economy against the ups and downs of the US market. By 2020, specialists foresee a drop of around 5\% in US GDP, which for Mexico could render in a decline of at least $6 \%$, with the main transmission channel operating through the external sector [53].

In South Korea, unlike in Mexico, the government prioritised an export policy that used national inputs, forcing exporting companies to buy local goods. Not only exporting companies received this type of support, but also the companies that supplied exporting companies' inputs [54]. On the other side of the world, the large transnational companies established in Mexico after the commercial liberalisation, not only absorbed the national companies, but also arrived with their own input suppliers. Therefore, as domestic production increased, so did imported inputs-known as temporary imports for export-generating a vicious circle of greater exports that led to greater imports, which, in turn, spawned a structural problem for Mexico. 
Table 1 shows that Mexico's exports and imports are mainly concentrated in the United States: $81 \%$ of Mexican exports and $45 \%$ of imports currently depend on its northern neighbour. Mexican exports to other single countries are of little significant weight; Canada is the second market for Mexican exports and only amounts to 3.1\%. There is a greater diversification of import markets, and it is worth noticing the growing penetration that Asian countries have had in Mexico; the second most important supplier to the Mexican market is China with a share of $18.2 \%$, while the third and fourth main suppliers are Japan and South Korea, which add up to $7.6 \%$ together.

A relevant characteristic in the trade relationship between Mexico and South Korea is that both countries have had competitive advantages that are reflected in the greater penetration of the bilateral market. Mexican exports to South Korea have grown at an average annual rate of $14 \%$ in the last twenty years, a growth rate in trade that is only below that of China. Regarding imports, South Korea has been the most dynamic market to supply Mexico with merchandise after China.

South Korea offers a completely different situation from the one in Mexico, given its greater commercial diversification. Table 2 shows that $70 \%$ of Korean exports go to ten countries; its main market is China, with a share of just over $26 \%$ of total exports, followed by the United States, with $12 \%$ and Vietnam with $8 \%$. Imports also show greater diversification; China is Korea's main supplier, with a $20 \%$ share of total imports, followed by the United States with $11 \%$ and Japan with $10 \%$, for a combined share of just $41 \%$.

Table 1. Exports and Imports by Country: Mexico 2000-2019.

\begin{tabular}{|c|c|c|c|c|c|}
\hline \multicolumn{6}{|l|}{ Exports } \\
\hline Country & $2000^{1}$ & Share ${ }^{2}$ & $2019^{1}$ & Share $^{2}$ & Growth $^{3}$ \\
\hline United States & $147,399,940$ & 88.73 & $371,043,634$ & 80.47 & 4.98 \\
\hline Canada & $3,340,006$ & 2.01 & $14,319,349$ & 3.11 & 7.96 \\
\hline China & 203,586 & 0.12 & $7,130,476$ & 1.55 & 20.58 \\
\hline Brazil & 517,222 & 0.31 & $4,297,631$ & 0.93 & 11.79 \\
\hline Colombia & 461,791 & 0.28 & $3,534,222$ & 0.77 & 11.31 \\
\hline Spain & $1,502,995$ & 0.90 & $4,680,111$ & 1.01 & 6.16 \\
\hline Germany & $1,543,906$ & 0.93 & $7,099,455$ & 1.54 & 8.36 \\
\hline Japan & 930,535 & 0.56 & $4,102,349$ & 0.89 & 8.12 \\
\hline South Korea & 188,878 & 0.11 & $2,277,019$ & 0.49 & 14.00 \\
\hline Rest of the world & $10,031,878$ & 6.04 & $42,631,351$ & 9.25 & 7.91 \\
\hline Total & $166,120,737$ & 100 & $461,115,597$ & 100 & 5.52 \\
\hline \multicolumn{6}{|l|}{ Imports } \\
\hline United States & $127,534,433$ & 73.1 & $205,733,312$ & 45.19 & 2.55 \\
\hline China & $2,879,620$ & 1.65 & $83,052,518$ & 18.24 & 19.36 \\
\hline Japan & $6,465,683$ & 3.71 & $17,963,780$ & 3.95 & 5.53 \\
\hline South Korea & $3,854,833$ & 2.21 & $16,724,504$ & 3.67 & 8.03 \\
\hline Germany & $5,758,417$ & 3.3 & $17,689,763$ & 3.89 & 6.08 \\
\hline Canada & $4,016,558$ & 2.3 & $9,842,987$ & 2.16 & 4.83 \\
\hline Rest of the world & $23,948,279$ & 13.73 & $104,288,423$ & 22.91 & 8.05 \\
\hline Total & $174,457,823$ & 100 & $455,295,287$ & 100 & 5.18 \\
\hline
\end{tabular}


Table 2. Exports and Imports by Country: South Korea 2000-2018.

\begin{tabular}{|c|c|c|c|c|c|}
\hline \multicolumn{6}{|c|}{ Exports } \\
\hline Country & $2000^{1}$ & Share $^{2}$ & Country & $2018^{1}$ & Share $^{2}$ \\
\hline United States & $37,610,630$ & 21.83 & China & $162,124,668$ & 26.81 \\
\hline Japan & $20,466,016$ & 11.88 & United States & $73,043,816$ & 12.08 \\
\hline China & $18,454,540$ & 10.71 & Vietnam & $48,622,095$ & 8.04 \\
\hline Hong Kong & $10,708,094$ & 6.22 & Hong Jong & $45,978,661$ & 7.60 \\
\hline Taiwan & $8,026,625$ & 4.66 & Japan & $30,527,116$ & 5.05 \\
\hline Singapore & $5,648,189$ & 3.28 & India & $15,606,221$ & 2.58 \\
\hline United Kingdom & $5,379,833$ & 3.12 & Philippines & $12,037,254$ & 1.99 \\
\hline Germany & $5,153,833$ & 2.99 & Singapore & $11,782,182$ & 1.95 \\
\hline Malaysia & $3,514,693$ & 2.04 & Mexico & $11,458,233$ & 1.89 \\
\hline Indonesia & $3,504,036$ & 2.03 & Australia & $9,610,270$ & 1.59 \\
\hline Rest of the world & $53,801,021$ & 31.23 & Rest of the world & $184,016,802$ & 30.43 \\
\hline Total & $172,267,510$ & 100 & Total & $604,807,317$ & 100 \\
\hline \multicolumn{6}{|l|}{ Imports } \\
\hline Country & $2000^{1}$ & Share $^{2}$ & Country & $2018^{1}$ & Share $^{2}$ \\
\hline Japan & $31,827,943$ & 19.83 & China & $106,487,854$ & 19.90 \\
\hline United States & $29,241,628$ & 18.22 & United States & $59,080,559$ & 11.04 \\
\hline China & $12,798,728$ & 7.98 & Japan & $54,603,331$ & 10.20 \\
\hline Saudi Arabia & $9,641,492$ & 6.01 & Saudi Arabia & $26,335,761$ & 4.92 \\
\hline Australia & $5,958,700$ & 3.71 & Germany & $20,853,089$ & 3.90 \\
\hline Indonesia & $5,286,908$ & 3.29 & Australia & $20,717,136$ & 3.87 \\
\hline Malaysia & $4,877,958$ & 3.04 & Vietnam & $19,643,385$ & 3.67 \\
\hline United Arab Emirates & $4,702,598$ & 2.93 & Russia & $17,503,932$ & 3.27 \\
\hline Taiwan & $4,700,740$ & 2.93 & Qatar & $16,293,627$ & 3.04 \\
\hline Germany & $4,624,655$ & 2.88 & Kuwait & $12,794,285$ & 2.39 \\
\hline Rest of the world & $46,819,668$ & 29.17 & Rest of the world & $180,870,415$ & 33.80 \\
\hline Total & $160,481,018$ & 100 & Total & $535,183,373$ & 100 \\
\hline
\end{tabular}

Mexico did not figure as one of the most important goods markets for South Korea back in the year 2000. However, by 2018, Mexico represented the ninth market (2\%) for Korean exports. It is relevant to point out that Chile, Peru, Colombia and the Central American Integration System (made up of Nicaragua, Costa Rica, Honduras and El Salvador) have free trade agreements with South Korea, but Mexico has, for instance, a greater weight than Chile as a supplier of imports, despite not having a trade agreement of such magnitude. In 2018, 0.95\% of Korean imports came from Mexico, while $0.84 \%$ came from Chile, despite the fact that the latter country signed its trade agreement in 2004.

The United States is one of the main consumers and suppliers in the world, only matched and in some cases surpassed by China; therefore, it is relevant to examine the way in which Mexico and South Korea have been inserted in both the Chinese and the American markets. Table 3 presents the main markets for US exports and imports. The first obvious fact is that, although Mexico maintains a high commercial dependency with the US, the dependency is not mutual. The United States retains Canada as the main trading partner for its exports and Mexico as the second partner in the period 2000-2018. It is noteworthy that the countries that provide imports to the US are led by China, which contributes $22 \%$ of total imports in 2018, displacing Mexico (13\%) and Canada (12\%), all of it without counting on a trade agreement like NAFTA. 
Table 3. Exports and Imports by Country: United States 2000-2018.

\begin{tabular}{|c|c|c|c|c|c|}
\hline \multicolumn{6}{|l|}{ Exports } \\
\hline Country & $2000^{1}$ & Share $^{2}$ & $2018^{1}$ & Share ${ }^{2}$ & Growth ${ }^{3}$ \\
\hline Canada & $178,919,985$ & 22.88 & $299,744,493$ & 18.00 & 2.75 \\
\hline Mexico & $111,338,635$ & 14.24 & $265,434,783$ & 15.94 & 4.68 \\
\hline China & $16,184,679$ & 2.07 & $120,147,866$ & 7.21 & 11.13 \\
\hline Japan & $64,921,645$ & 8.30 & $75,226,086$ & 4.52 & 0.78 \\
\hline United Kingdom & $41,569,587$ & 5.32 & $66,293,664$ & 3.98 & 2.49 \\
\hline Germany & $29,445,968$ & 3.77 & $57,332,502$ & 3.44 & 3.57 \\
\hline South Korea & $27,829,956$ & 3.56 & $56,504,532$ & 3.39 & 3.80 \\
\hline Netherlands & $21,835,273$ & 2.79 & $48,689,211$ & 2.92 & 4.31 \\
\hline Brazil & $15,320,854$ & 1.96 & $39,559,841$ & 2.38 & 5.12 \\
\hline France & $20,517,445$ & 2.62 & $37,649,478$ & 2.26 & 3.25 \\
\hline Hong Kong & $14,580,493$ & 1.86 & $37,284,154$ & 2.24 & 5.07 \\
\hline India & $3,667,128$ & 0.47 & $33,502,787$ & 2.01 & 12.35 \\
\hline Singapore & $17,806,130$ & 2.28 & $32,729,753$ & 1.97 & 3.26 \\
\hline Belgium & $13,924,406$ & 1.78 & $31,426,689$ & 1.89 & 4.38 \\
\hline Rest of the world & $203,968,488$ & 26.09 & $463,777,100$ & 27.85 & 4.42 \\
\hline Total & $781,830,673$ & 7.70 & $1,665,302,937$ & 100 & 4.06 \\
\hline \multicolumn{6}{|l|}{ Imports } \\
\hline Country & $2000^{1}$ & Share $^{2}$ & $2018^{1}$ & Share $^{2}$ & Growth ${ }^{3}$ \\
\hline China & $100,012,903$ & 8.21 & $563,203,120$ & 21.57 & 9.52 \\
\hline Canada & $230,816,138$ & 18.95 & $325,683,551$ & 12.47 & 1.83 \\
\hline Mexico & $135,923,121$ & 11.16 & $349,195,245$ & 13.37 & 5.09 \\
\hline Japan & $146,479,387$ & 12.03 & $145,902,253$ & 5.59 & -0.02 \\
\hline Germany & $58,511,298$ & 4.80 & $128,345,618$ & 4.91 & 4.22 \\
\hline South Korea & $40,307,624$ & 3.31 & $76,200,587$ & 2.92 & 3.41 \\
\hline United Kingdom & $43,333,410$ & 3.56 & $61,748,826$ & 2.36 & 1.88 \\
\hline Ireland & $16,463,577$ & 1.35 & $57,679,282$ & 2.21 & 6.82 \\
\hline India & $10,686,244$ & 0.88 & $56,443,792$ & 2.16 & 9.15 \\
\hline Italy & $25,041,357$ & 2.06 & $56,256,198$ & 2.15 & 4.35 \\
\hline France & $29,833,154$ & 2.45 & $53,621,602$ & 2.05 & 3.13 \\
\hline Vietnam & 821,430 & 0.07 & $51,277,489$ & 1.96 & 24.31 \\
\hline Rest of the world & $379,703,331$ & 31.18 & $685,874,927$ & 26.26 & 3.16 \\
\hline Total & $1,217,932,974$ & 100 & $2,611,432,490$ & 100 & 4.10 \\
\hline
\end{tabular}

The weight of South Korea in US exports and imports is very stable, representing approximately $3 \%$ of exports and 3\% of imports in 2018. Both Mexico and Korea show sustained growth in their trade with the United States; in the period, the weight of exports from the latter country to Mexico has grown at an annual rate of $5 \%$ and its purchases via imports at about $5 \%$ as well. The Korean dynamic is slightly lower than the Mexican, registering rates below 4\% annually. Despite the strong Chinese penetration in the US market, Mexico continues to be the second most important destination for US products, and is also its second most important supplier.

\section{Trade Policy and Diversification in México}

Under the above circumstances, Mexico needs to rethink some of its policies of international insertion, and among these should be the diversification in destination countries of the goods it exports. Faced with the growth of Asian markets and the more protectionist policies of the Trump administration, the high concentration of Mexican trade in the US is a continuous risk that may even contravene Mexican sovereignty. This risk was particularly poignant during the NAFTA renegotiations in November 2018, when President Trump continually threatened the Mexican government with the 
unilateral imposition of tariffs in order to pressure President López Obrador to make concessions within the new trade agreement. Negotiations eventually led to the new Treaty between Mexico, the United States and Canada (TMEC).

If we compare the concentration of Mexican foreign trade with that of the most relevant economies in Latin America, it is possible to verify that Mexico has the least commercial diversification. Table 4 presents the results of the Hirschman-Herfindahl Index (HHI), which is defined as $H H I=\frac{\sum\left(\frac{V_{i}}{V_{t}}\right)^{2}-\frac{1}{n}}{1-\frac{1}{n}}$, where $V_{i}$ are exports from a given country to the partner country $i, V_{t}$ is total value of exports to all partner countries and $n$ is the number of countries in the world. The resulting index, HHI, varies between 0 and 1 , where 0 indicates total diversification and 1 indicates total concentration.

Table 4. Hirschman-Herfindahl Index (Trade Concentration Index) in Latin America.

\begin{tabular}{lll}
\hline Country & $\mathbf{2 0 0 0}$ & $\mathbf{2 0 1 8}$ \\
\hline Argentina & 0.10 & 0.05 \\
\hline Bolivia & 0.11 & 0.08 \\
\hline Brazil & 0.09 & 0.10 \\
\hline Colombia & 0.27 & 0.10 \\
\hline Uruguay & 0.10 & 0.10 \\
\hline Peru & 0.10 & 0.12 \\
\hline Ecuador & 0.17 & 0.12 \\
\hline Chile & 0.07 & 0.15 \\
\hline Paraguay & 0.45 & 0.16 \\
\hline Costa Rica & 0.28 & 0.18 \\
\hline El Salvador & 0.15 & 0.25 \\
\hline Nicaragua & 0.18 & 0.40 \\
\hline Mexico & 0.78 & 0.67 \\
\hline
\end{tabular}

Source: authors' estimations using data from Graphic System of International Trade (SIGCI)-Economic Commission for Latin America and the Caribbean (ECLAC) [57].

We can observe an index of 78\% in 2000 and of $67 \%$ for Mexico in 2018, which indicates that, although the concentration of Mexican exports decreased slightly, it was not enough to reach export diversification, since the concentration index is still high. As mentioned, Mexico is the country with the highest concentration in Latin America and is in sharp contrast with the high degree of commercial diversification in other important economies in the region, like Argentina, Brazil and Chile.

The lack of diversification in the destination of Mexico's international trade is also in contrast with the large number of free trade agreements it holds with over 45 countries, among which are the United States, Canada, the European Union, Japan and some Latin American countries, as shown in Table 5. Mexico also has 32 Agreements for the Reciprocal Promotion and Protection of Investments (APPRI) with 33 countries, and nine agreements of limited scope (Economic Complementation Agreements and Partial Scope Agreements) within the framework of the Latin American Integration Association (ALADI). However, the high commercial dependency to the US is an indicator that not enough advantage has been taken from said agreements to modify the pattern of Mexican commercial concentration. 
Table 5. Selected Free Trade Agreements in force in Mexico.

\begin{tabular}{llr}
\hline \multicolumn{1}{c}{ Agreement } & \multicolumn{1}{c}{ Countries } & Entry into Force \\
\hline NAFTA & Mexico, United States and Canada & 1 January 1994 \\
\hline FTA Mexico-Colombia & Mexico and Colombia & 2 August 2011 \\
\hline FTA Mexico-Costa Rica & Mexico and Costa Rica & 1 January 1995 \\
\hline FTA Mexico-Nicaragua & Mexico and Nicaragua & 1 July 1998 \\
\hline FTA Mexico-Chile & Mexico and Chile & 1 August 1999 \\
\hline EU FTA Mexico-European Union & Mexico and European Union Member Countries & 1 July 2000 \\
\hline FTA Mexico-Israel & Mexico and Israel & 1 July 2000 \\
\hline FTA Mexico-Northern Triangle & Mexico, El Salvador, Guatemala and Honduras & 14 March 2000 \\
\hline FTA Mexico-Uruguay & Mexico and Uruguay & 15 July 2004 \\
\hline FTA Mexico-European Free Trade & Mexico, Iceland, Liechtenstein, Norway and & 1 October 2001 \\
Association (EFTA) & Switzerland & 22 November 2011 \\
\hline FTA Único Mexico-Central America & Mexico, Costa Rica, El Salvador, Guatemala, & Honduras and Nicaragua \\
\hline
\end{tabular}

Source: countries with treaties and agreements signed with Mexico, Ministry of Economy, Mexico.

A remarkable standout from the numerous trade agreements that Mexico has signed is the absence of South Korea, in spite of already having a notable presence as a trading partner for Mexico. Although Mexico and Korea have maintained official diplomatic relations since January 26, 1962, diplomatic contacts and trade flows between the two countries were not relevant until the 1980s and, therefore, few bilateral treaties and agreements existed [58]. Almost twenty bilateral agreements have been established between Mexico and the Republic of Korea, most of them since the 1990s, and their main interest has been regulating the economic relationship in matters that require more immediate attention, which are easier to tackle through more basic agreements, than through a more integral Free Trade Agreement.

There is a process of negotiation between Mexico and South Korea that has been stalled since 2007. So far, negotiations have not prospered, and the Mexican government has settled for cultivating the current bilateral trade relationship. However, the greater strength of trade relations between the two countries makes it relevant to reflect on the advantages that such an agreement would have in Mexico if it resumed and speeded trade negotiations with the Korean government.

In principle, it should be borne in mind that South Korea represents a huge potential market due to its economic size-it is the fourteenth world economy and the sixth in Asia according to its GDP per capita. The country imports such a large number of goods annually that it ranks among the top ten world importers. Food is one of the main imports, which opens the possibility for the Mexican agricultural sector to find an escape valve to the structural crisis it has had for decades. Mexico could also become a potential exporter for the second imports sector in Korea, which are fuels and mineral products.

Concluding trade negotiations with South Korea would enable the elimination or reduction of the currently high tariffs for trading with Mexico and it would establish a preference over other Latin American countries, with the exception of Chile and Peru, who already have trade agreements with the Korean government. The achievement of a trade agreement should not be underestimated; according to data from the Mexican Ministry of the Economy, Mexican exports to South Korea have grown at an average annual rate of $21 \%$ from 1993 to $27 \%$ in 2019 . A system of trade preferences would avoid paying the current weighted tariffs for the agricultural sector, which exceed $100 \%$, and could increase exports and imports of both countries bringing mutual benefit to both nations.

Achieving a successful trade agreement between South Korea and Mexico is also highly relevant for Korea's incorporation to the Pacific Alliance, a commercial and economic initiative integrated by Mexico, Colombia, Chile and Peru, given that it is a necessary condition for any country attempting to 
become an associated state to have a free trade agreement with all countries in the Alliance and Korea is only lacking such agreement with Mexico to meet this requirement.

In sum, a Mexico-Korea FTA would strengthen the strategic position of both countries in the Pacific region, in addition to providing Mexico with an alternative for commercial diversification.

\section{Methodology and Results}

In order to fulfil the proposed objective, on the one hand, to analyse the commercial complementarity between the two countries-Mexico and Korea-we use a set of export indices: the export intensity index, the similarity index and the Grubel-Lloyd index. To assess the long-term balance in trade between the two economies, we employ the Thirlwall trade restriction model.

\subsection{Trade Complementarity}

The data used here are publicly available from the Graphic System of International Trade (SIGCI) of the Economic Commission for Latin America and the Caribbean (ECLAC) for the years 2000 and 2018. The indices used to analyse the complementarity between the two countries are shown in Table 6 .

Table 6. Export Indices.

\begin{tabular}{|c|c|c|c|}
\hline Indicator & Formula & Variables & Interpretation \\
\hline $\begin{array}{l}\text { Similarity } \\
\text { Index }\end{array}$ & $S I=\sum_{k=1}^{n} \operatorname{Min}\left[\frac{x_{i}^{k}}{x_{i}}, \frac{x_{j}^{k}}{x_{j}}\right]$ & $\begin{array}{l}x_{i}^{k}: \text { from country } i \\
x_{j}^{k}: \text { exports of product } k \text { from country } j \\
x_{i}: \text { total exports from country } i \\
x_{j}: \text { total exports from country } j \\
n: \text { total number of SITC }{ }^{*} \text { products. }\end{array}$ & $\begin{array}{l}\text { The index goes from } 0 \text { to } 1 \text {. } \\
\text { If the two countries have different } \\
\text { export structures, the index value } \\
\text { will be zero. } \\
\text { Approaching an index of one, the } \\
\text { export structures of both countries } \\
\text { are similar. }\end{array}$ \\
\hline $\begin{array}{l}\text { Grubel-Lloyd } \\
\text { Index }\end{array}$ & $G L I=1-\frac{\sum_{k}\left|X_{i j}^{k}-M_{i j}^{k}\right|}{\sum_{k}\left(X_{i j}^{k}+M_{i j}^{k}\right)}$ & $\begin{array}{l}X: \text { exports } \\
M: \text { imports } \\
i: \text { country } \\
j: \text { partner country } \\
k \text { : economic sector ( } 3 \text { SITC digits: Standard } \\
\text { International Trade Classification) }\end{array}$ & $\begin{array}{l}\text { The index goes from } 0 \text { to } 1 \\
\text { GLI }>0.33 \text { : intra-industrial trade } \\
0.10 \geq G L I \leq 0.33 \text { : moderate } \\
\text { intra-industrial trade } \\
0 \geq G L I \leq 0.1: \text { inter-industrial trade } \\
\text { GLI } \approx 1: \text { mainly intra-industrial } \\
\text { bilateral trade } \\
\text { GLI } \approx 0 \text { : mainly inter-industrial } \\
\text { bilateral trade }\end{array}$ \\
\hline
\end{tabular}

Source: SIGCI-ECLAC [57].

Table 7 shows the Export Intensity Index for South Korea in 2000 and 2018. We can see that around $80 \%$ of Korean exports are sent to 20 countries, led by China and the United States. Mexico has climbed in the export intensity index for Korea from the fifteenth position in 2000 to the tenth in 2018, and could ascend even more if the trade agreement were signed by both countries.

For Mexico, the presence of South Korea in the national market is also important, as shown in Table 8. If we refer to the export intensity index for Mexico, we can appreciate that South Korea did not appear in the first 20 positions in 2000, but by 2018, it rose to tenth position. While Mexico climbed five places in Korea's index, Korea did so more quickly advancing more than 10 places in Mexico's index, thus placing both countries in the tenth place of importance for each other. Those ranking positions could be further advanced if both countries did their best to sign the trade agreement, especially in products that are indispensable for both economies. 
Table 7. Export Intensity Index: South Korea 2000-2018.

\begin{tabular}{|c|c|c|c|c|c|c|}
\hline \multicolumn{4}{|c|}{2000} & \multicolumn{3}{|c|}{2018} \\
\hline Rank & Country & Share ${ }^{1}$ & Cum $^{2}$ & Country & Share ${ }^{1}$ & Cum $^{2}$ \\
\hline 1 & USA & 21.95 & 21.95 & China & 26.81 & 26.81 \\
\hline 2 & Japan & 11.88 & 33.83 & USA & 12.08 & 38.88 \\
\hline 3 & China & 10.71 & 44.54 & Vietnam & 8.04 & 46.92 \\
\hline 4 & China, Hong Kong SAR & 6.22 & 50.76 & China, Hong Kong SAR & 7.60 & 54.52 \\
\hline 5 & Other Asia, NES & 4.66 & 55.41 & Japan & 5.05 & 59.57 \\
\hline 6 & Singapore & 3.28 & 58.69 & Other Asia, NES & 3.44 & 63.01 \\
\hline 7 & United Kingdom & 3.12 & 61.82 & India & 2.58 & 65.59 \\
\hline 8 & Germany & 2.99 & 64.81 & Philippines & 1.99 & 67.58 \\
\hline 9 & Malaysia & 2.04 & 66.85 & Singapore & 1.95 & 69.53 \\
\hline 10 & Indonesia & 2.03 & 68.88 & Mexico & 1.89 & 71.42 \\
\hline 11 & Philippines & 1.95 & 70.83 & Australia & 1.59 & 73.01 \\
\hline 12 & Netherlands & 1.54 & 72.38 & Germany & 1.55 & 74.56 \\
\hline 13 & Australia & 1.51 & 73.89 & Malaysia & 1.49 & 76.05 \\
\hline 14 & Canada & 1.41 & 75.3 & Indonesia & 1.46 & 77.51 \\
\hline 15 & Mexico & 1.39 & 76.69 & Thailand & 1.40 & 78.91 \\
\hline 16 & Thailand & 1.17 & 77.86 & Russia & 1.21 & 80.12 \\
\hline 17 & United Arab Emirates & 1.16 & 79.01 & United Kingdom & 1.05 & 81.17 \\
\hline 18 & Italy & 1.11 & 80.12 & Turkey & 0.99 & 82.16 \\
\hline 19 & France & 1.02 & 81.14 & Canada & 0.95 & 83.11 \\
\hline 20 & Brazil & 1.00 & 82.14 & Brazil & 0.81 & 83.92 \\
\hline
\end{tabular}

${ }^{1}$ Percentage. ${ }^{2}$ Cumulative share, percentage. Source: authors' estimations using data from SIGCI-ECLAC [57].

Another relevant indicator of the trade complementarity between South Korea and Mexico has to do with the degree of similarity of the products they trade with each other. Table 9 presents this export similarity and shows that Mexico's exports to South Korea are less similar than those of its main trading partners. Additionally, we can see that the similarity index has decreased in the period, which means that the products exported by Mexico to Korea tend to show different export structures. When the reference country is South Korea, the index shows that the export structure with Mexico has slightly increased its similarity.

Mexico mainly imports electronic components, semiconductors and electronic inputs from Korea for its automotive and aerospace industries, up to $50 \%$ of Mexican imports from Korea concentrate in 25 tariff fractions of these products in 2019, according to trade data from the Mexican Ministry of Finance. On the other side, Mexico exports mainly minerals, auto parts and food products to Korea; the four main tariff items are for exports of zinc, lead, silver and automatic transmissions; these alone represented $18 \%$ of Mexican exports to Korea. 
Table 8. Export Intensity Index: Mexico 2000-2018.

\begin{tabular}{|c|c|c|c|c|c|c|}
\hline \multirow[b]{2}{*}{ Rank } & \multicolumn{3}{|c|}{2000} & \multicolumn{3}{|c|}{2018} \\
\hline & Country & Share & Cum $^{1}$ & Country & Share & Cum $^{1}$ \\
\hline 1 & USA & 88.16 & 88.16 & USA & 76.78 & 76.78 \\
\hline 2 & Canada & 2.15 & 90.31 & Areas, NES & 5.86 & 82.63 \\
\hline 3 & Spain & 0.93 & 91.24 & Canada & 3.08 & 85.71 \\
\hline 4 & Germany & 0.93 & 92.17 & China & 1.58 & 87.29 \\
\hline 5 & Japan & 0.67 & 92.84 & Germany & 1.57 & 88.86 \\
\hline 6 & Netherlands Antilles & 0.52 & 93.36 & Brazil & 0.92 & 89.78 \\
\hline 7 & United Kingdom & 0.51 & 93.87 & Colombia & 0.77 & 90.55 \\
\hline 8 & Brazil & 0.41 & 94.29 & Japan & 0.73 & 91.28 \\
\hline 9 & Venezuela & 0.36 & 94.65 & Netherlands & 0.53 & 91.8 \\
\hline 10 & Guatemala & 0.34 & 94.99 & South Korea & 0.5 & 92.31 \\
\hline 11 & Chile & 0.33 & 95.32 & United Kingdom & 0.49 & 92.8 \\
\hline 12 & Dominican Republic & 0.32 & 95.64 & Guatemala & 0.42 & 93.22 \\
\hline 13 & Colombia & 0.3 & 95.94 & Belgium & 0.42 & 93.64 \\
\hline 14 & Netherlands & 0.24 & 96.18 & Chile & 0.41 & 94.05 \\
\hline 15 & Costa Rica & 0.21 & 96.39 & France & 0.39 & 94.43 \\
\hline 16 & Argentina & 0.2 & 96.6 & Spain & 0.38 & 94.81 \\
\hline 17 & France & 0.2 & 96.79 & Italy & 0.38 & 95.19 \\
\hline 18 & Belgium & 0.19 & 96.98 & Peru & 0.36 & 95.55 \\
\hline 19 & China & 0.19 & 97.17 & India & 0.3 & 95.84 \\
\hline 20 & El Salvador & 0.18 & 97.35 & Argentina & 0.27 & 96.11 \\
\hline
\end{tabular}

Table 9. Similarity Index.

\begin{tabular}{lcc}
\hline \multicolumn{1}{c}{ Mexico } & & \\
\hline USA & $\mathbf{2 0 0 0}$ & $\mathbf{2 0 1 8}$ \\
\hline Canada & 0.52 & 0.53 \\
\hline China & 0.54 & 0.50 \\
\hline South Korea & 0.53 & 0.48 \\
\hline South Korea & 0.49 & 0.39 \\
\hline Country & & \\
\hline Japan & $\mathbf{2 0 0 0}$ & $\mathbf{2 0 1 8}$ \\
\hline USA & 0.58 & 0.61 \\
\hline Mexico & 0.53 & 0.53 \\
\hline China & 0.49 & 0.51 \\
\hline Total & 0.47 & 0.39 \\
\hline Source: authors' estimations using data from SIGCI-ECLAC [57].
\end{tabular}

Results for the Grubel-Lloyd Index (GLI) in Table 10 indicate that trade between Mexico and South Korea is moderately inter-industrial, which means that there is a limited trade relationship between different types of industries in the two countries, a situation that reflects a mild degree of 
productive complementarity. For both countries, trade relations with their main partners account for a GLI greater than 0.3, which is an indication of marked inter-industrial trade.

Table 10. Grubel-Lloyd Index (GLI).

\begin{tabular}{lr}
\hline Mexico & \\
\hline Country & $\mathbf{2 0 1 8}$ \\
\hline USA & 0.45 \\
\hline Canada & 0.38 \\
\hline South Korea & 0.13 \\
\hline South Korea & \\
\hline Country & $\mathbf{2 0 1 8}$ \\
\hline Japan & 0.49 \\
\hline China & 0.47 \\
\hline USA & 0.38 \\
\hline Mexico & 0.22 \\
\hline Total & $\mathbf{1 0 0}$ \\
\cline { 2 - 2 } Source: authors' estimations using data from SIGCI-ECLAC [57].
\end{tabular}

\subsection{Long-Term Equilibrium in Exports and Imports: Thirlwall's Cointegration Model}

Thirlwall [39] developed a model where the economic growth of a country depends on the economic evolution of its trading partners-the rest of the world-which can be explained through the demand for exports and imports. The model highlights the role of demand and stresses that no country can grow faster than the rate consistent with equilibrium in the current account on the balance of payments, unless it can be constantly financed, which, by rule, cannot generally be done. In what follows, we will formalise the Thirlwall model, beginning from the export and import demand functions that express the trade openness or commercial relationship:

$$
\begin{aligned}
X_{i t} & =\left(\frac{P_{d, i t}}{P_{f, i t} E_{i t}}\right)^{\eta} Z^{\varepsilon} \\
M_{i t} & =\left(\frac{P_{f, i t} E_{i t}}{P_{d, i t}}\right)^{\psi} Y^{\pi}
\end{aligned}
$$

Consider a country $\mathrm{i}-$ South Korea-in a commercial relationship with Mexico, given a period of time $t$, where $X_{i t}$ is the level of exports to country $i$ in period $t$. Then, $P_{d, i t}$ is the export price index, $P_{f, i t}$ is the price index of import demand, $\mathrm{E}_{\mathrm{it}}$ is the nominal exchange rate and $\mathrm{Z}$ expresses the income level of the Korean economy, and $\psi, \pi, \eta$ and $\varepsilon$ are the price elasticity of imports, the income elasticity of imports, the price elasticity of exports and the income elasticity of exports, respectively. The model starts from equilibrium in the current account in the next structural equation:

$$
\mathrm{P}_{\mathrm{d}, \mathrm{it}} \mathrm{X}_{\mathrm{it}}=\mathrm{P}_{\mathrm{f}, \mathrm{it}} \mathrm{M}_{\mathrm{it}} \mathrm{E}_{\mathrm{it}}
$$

Transforming Equations (1)-(3) into logarithms, we have:

$$
\begin{gathered}
\mathrm{p}_{\mathrm{d}, \mathrm{it}}+\mathrm{x}_{\mathrm{it}}=\mathrm{p}_{\mathrm{f}, \mathrm{it}}+\mathrm{m}_{\mathrm{it}}+\mathrm{e}_{\mathrm{it}} \\
\mathrm{x}_{\mathrm{it}}=\eta\left(\mathrm{p}_{\mathrm{d}, \mathrm{it}}-\mathrm{e}_{\mathrm{it}}-\mathrm{p}_{\mathrm{f}, \mathrm{it}}\right)+\varepsilon \mathrm{Z}_{\mathrm{it}} \\
\mathrm{m}_{\mathrm{it}}=\psi\left(\mathrm{p}_{\mathrm{f}, \mathrm{it}}+\mathrm{e}_{\mathrm{it}}-\mathrm{p}_{\mathrm{d}, \mathrm{it}}\right)+\pi \mathrm{y}_{\mathrm{it}}
\end{gathered}
$$


Substituting Equations (5) and (6) in Equation (2), and solving for $\mathrm{y}_{\text {it }}$ we obtain:

$$
\mathrm{y}_{\mathrm{it}}=\frac{(1+\eta+\psi)\left(\mathrm{p}_{\mathrm{d}, \mathrm{it}}-\mathrm{p}_{\mathrm{f}, \mathrm{it}}-\mathrm{e}_{\mathrm{it}}\right)+\varepsilon \mathrm{Z}_{\mathrm{it}}}{\pi}
$$

McCombie and Thirlwall [59] considered that, given the empirical evidence in several long-term models, the differences in relative prices in a common currency are relatively minimal. Therefore, Equations (5) and (6) can be expressed in their simple form with the following logarithmic transformations:

$$
\begin{aligned}
& \ln x_{i t}=\alpha+\varepsilon \operatorname{lnyf} f_{i t}+\eta \operatorname{lntcr} r_{i t}+u_{i t} \\
& \operatorname{lnm}_{i t}=\alpha+\pi \ln y_{i t}+\psi \operatorname{lntcr} r_{i t}+u_{i t}
\end{aligned}
$$

where:

$\ln x_{i t}=$ logarithm of Mexican exports to South Korea in purchasing power parity dollars, $\operatorname{lnm}_{i t}=$ logarithm of Mexican imports from South Korea in purchasing power parity dollars, $\operatorname{lny} f_{i t}=$ logarithm of South Korea's GDP in purchasing power parity dollars, $\operatorname{lntcr}_{i t}=$ logarithm of the real exchange rate from Mexican pesos to dollars, $\operatorname{lny}_{\mathrm{it}}=$ logarithm of Mexico's GDP in purchasing power parity dollars.

Figure 1 graphs the model variables; both panels show that the series are not stationary and maintain an increasing trend. Weak stationarity entails that the mean and variance of the variables are finite and do not depend on time. This is a necessary condition in econometric models to avoid spurious relations between the variables (see [60]).

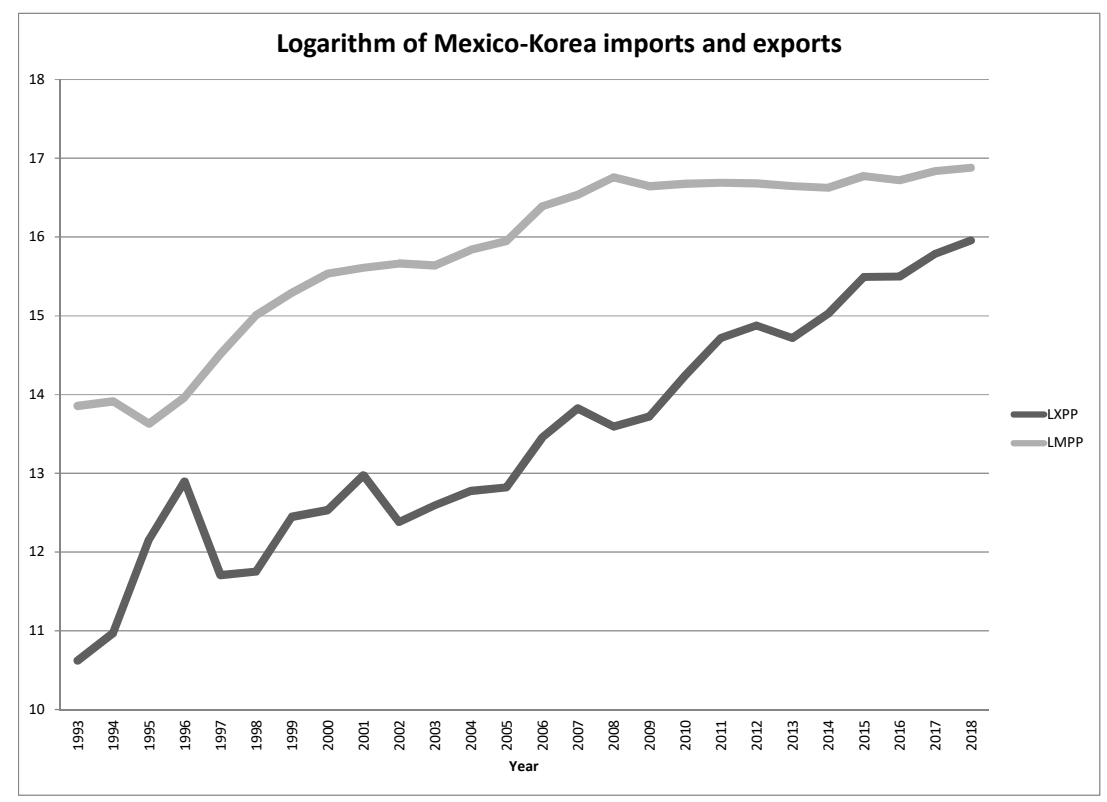

(a)

Figure 1. Cont. 


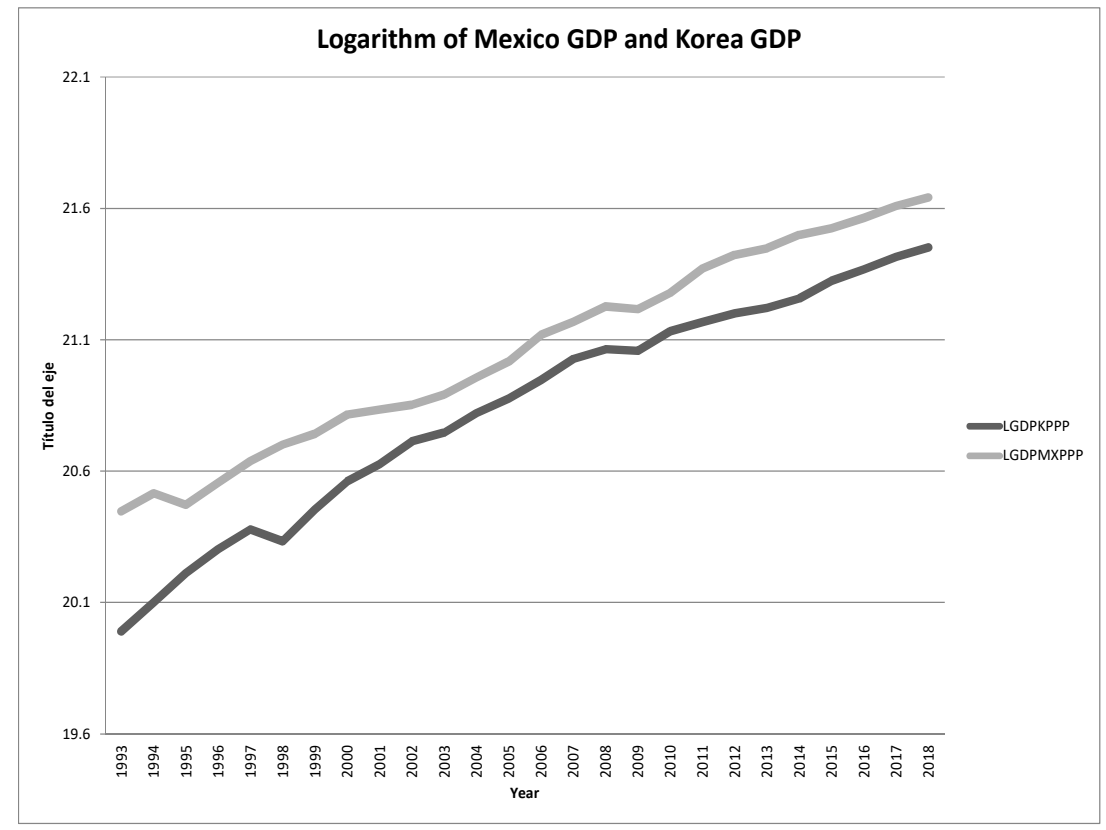

(b)

Figure 1. GDP, Exports and Imports in Mexico and South Korea, 1993-2018: (a) Imports and Exports Mexico-South Korea, logarithms; (b) Mexico's GDP and South Korea's GDP, logarithms. Source: authors' using data from The World Bank [61].

We performed individual unit root tests based on the proposal of Im, Pesaran and Shin (IPS henceforth) [62]. This proposal allows the null hypothesis of unit root to be tested using individual Dickey-Fuller tests while providing an average for the pool of variables. The IPS equation for each variable is an augmented Dickey-Fuller (ADF) test:

$$
\Delta y_{t}=\alpha y_{t-1}+\sum_{j=1}^{p} \beta_{j} \Delta y_{t-j}+X_{t} \delta+\varepsilon_{t}
$$

where $X_{t}$ represents exogenous variables, fixed effects or specific trends; $\delta$ is the coefficient for exogenous effects, $\alpha_{i}=\rho-1$ is an autoregressive coefficient and $\varepsilon_{t}$ is white noise. The null hypothesis of unit root is expressed simply as $H_{0}: \alpha_{i}=0$, but the test also allows to obtain the mean $E(t)$ and variance $E($ var $)$ of individual t-statistics from ADF tests, to arrive at a joint test for the presence of unit root.

Results are shown in Table 11, where we observe that the null hypothesis of unit root, cannot be rejected; individually, all the series have a $p$-value greater than $5 \%$, so we conclude that they are not stationary. 
Table 11. Im-Pesaran-Shin Unit Root Tests.

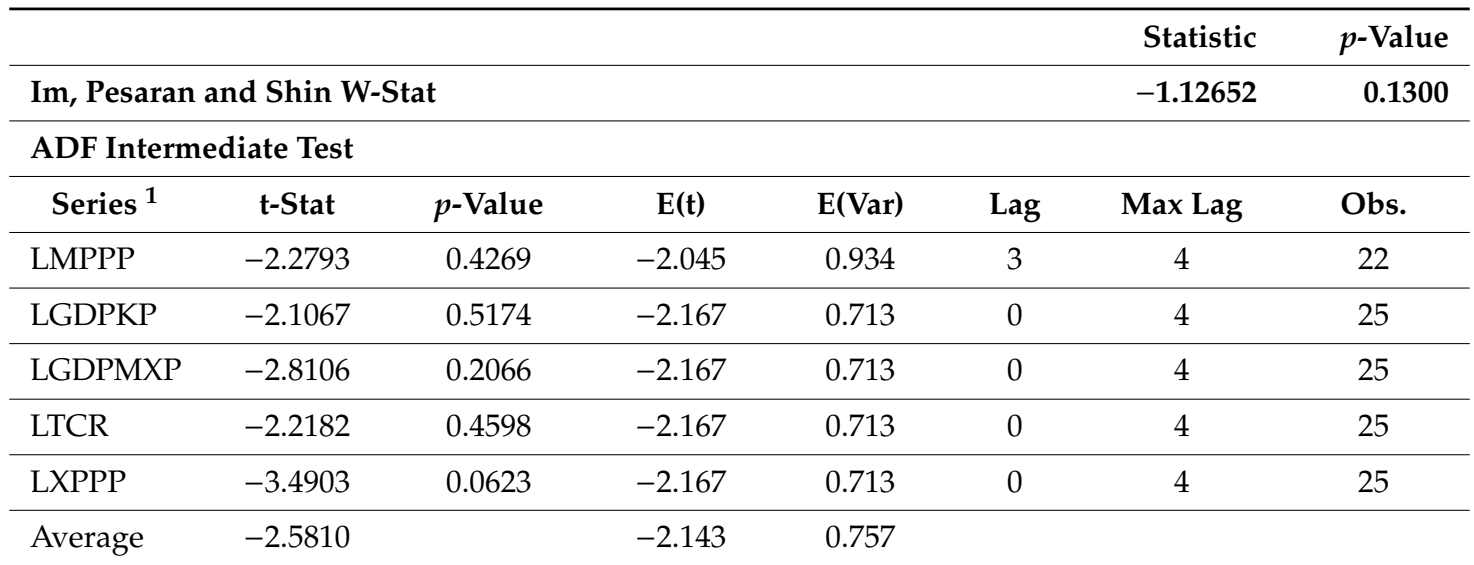

${ }^{1}$ LMPPP: logarithm of Korean imports from Mexico in purchasing parity power dollars; LGDPKP: logarithm of Korean GDP in purchasing parity power dollars; LGDPMXP: logarithm of Mexican GDP in purchasing parity power dollars; LTCR: logarithm of the real exchange rate from Mexican pesos to dollars; LXPPP: logarithm of Exports from Mexico to South Korea in purchasing parity power dollars. The tests include trend and intercept. Source: authors' estimation using software EViews.

When performing the same test in first differences, the null hypothesis of unit root is rejected; thus, the variables become stationary in first differences, as shown in Table 12.

Table 12. Im-Pesaran-Shin Unit Root Tests in First Differences.

\begin{tabular}{|c|c|c|c|c|c|c|c|}
\hline & & & & & & Statistic & $p$-Value \\
\hline \multicolumn{6}{|c|}{ Im, Pesaran and Shin W-Stat } & -8.03011 & 0.0000 \\
\hline \multicolumn{8}{|c|}{ ADF Intermediate Test } \\
\hline Series & t-Stat & $p$-Value & $E(t)$ & $\mathrm{E}($ Var) & Lag & Max Lag & Obs. \\
\hline D(LMPPP) & -3.0515 & 0.0456 & -1.434 & 0.943 & 2 & 4 & 22 \\
\hline D(LGDPKP) & -4.6363 & 0.0012 & -1.520 & 0.817 & 0 & 4 & 24 \\
\hline D(LGDPMXP) & -5.3730 & 0.0002 & -1.520 & 0.817 & 0 & 4 & 24 \\
\hline $\mathrm{D}(\mathrm{LTCR})$ & -4.5443 & 0.0015 & -1.520 & 0.817 & 0 & 4 & 24 \\
\hline $\mathrm{D}(\mathrm{LXPPP})$ & -6.5142 & 0.0000 & -1.515 & 0.883 & 1 & 4 & 23 \\
\hline Average & -4.8239 & & -1.502 & 0.856 & & & \\
\hline
\end{tabular}

Source: authors' estimation using software EViews.

Once the existence of unit roots has been confirmed, we performed the Johansen cointegration test. The results shown in Table 13 indicate that there are at least three cointegration vectors.

Table 13. Johansen Cointegration Test.

\begin{tabular}{cccccc}
\hline \multicolumn{5}{c}{ Selected (0.05 Level) Number of Cointegrating Relations by Model } \\
\hline Data Trend & None & None & Linear & Linear & Quadratic \\
\hline Test Type & No Intercept & Intercept & Intercept & Intercept & Intercept \\
\hline No Trend & No Trend & No Trend & Trend & Trend \\
\hline Max-Eig & 3 & 4 & 3 & 3 & 4 \\
\hline
\end{tabular}

Source: authors' estimation using software EViews. 
We used the alternative canonical cointegration regression (CCR) to estimate the econometric model for the cointegration vectors in Equations (8) and (9). The CCR uses transformed data and allows representing the cointegration relations through an ordinary least squares (OLS) regression. Instead of performing stationary transformations, CCR transforms the variables through consistent estimates of long-run covariance matrices of the error terms that make for suitable inputs in OLS regressions. In addition, since exports and imports may be interrelated, CCR corrects for the asymptotic bias that results from contemporaneous correlations between the regression and stochastic regressor errors. These and more advantages of the method can be reviewed in the work of Joon Y. Park [63]. The results are shown below in Table 14.

Table 14. Results for the Export and Import Equations, 1994-2018.

\begin{tabular}{lrlr}
\hline \multicolumn{2}{c}{ Sample (Adjusted): 1994-2018 } & & \\
\multicolumn{1}{c}{ Exports } & & \multicolumn{2}{c}{ Imports } \\
\hline Variable ${ }^{1}$ & Coefficient & \multicolumn{1}{c}{ Variable $^{1}$} & Coefficient \\
\hline$p$-value & 3.252340 & LGDPXP & 2.545731 \\
\hline LTCR & 0.0000 & $p$-value & 0.0000 \\
\hline$p$-value & 2.515281 & LTCR & -2.152774 \\
\hline C & 0.0012 & $p$-value & 0.0015 \\
\hline$p$-value & -66.12694 & C & -27.73769 \\
\hline R-squared & 0.0000 & $p$-value & 0.0000 \\
\hline Adjusted R-squared & 0.928522 & R-squared & 0.921397 \\
\hline S.E. of regression & 0.922024 & Adjusted R-squared & 0.914252 \\
\hline
\end{tabular}

${ }^{1}$ LGDPKP: logarithm of Korean GDP in purchasing parity power dollars. LGDPMXP: logarithm of Mexican GDP in purchasing parity power dollars. LTCR: logarithm of the real exchange rate from Mexican pesos to dollars: the long-run covariance were estimated with Bartlett kernel, Newey-West fixed bandwidth. Source: authors' estimation of the canonical cointegration regression (CCR) using software EViews.

The results allow establishing that the income elasticity of exports (3.25) is greater than the income elasticity of imports (2.54), which, in principle, would endow Mexico with a greater export potential if trade relations with South Korea were deepened. We also observe that the elasticity of exports to the real exchange rate (2.51) is greater in absolute value than that of imports (2.15), therefore, the depreciation of the Mexican peso against the dollar would increase even more the export capacity relative to the reduction in imports.

According to Krugman [33], in perfect competition, countries with income elasticity from exports greater than income elasticity from imports could accelerate their growth rate without having to depreciate the real exchange rate in the long term. Thus, if the real exchange rate from Mexican pesos to dollars were equal to zero in the long term, the following condition would be met in Equation (7), and the maximum growth rate $(y *)$ could be reached, while keeping the trade balance in equilibrium:

$$
y^{*} i t=\frac{\varepsilon}{\pi} z_{i t}
$$

As reported by the results of the model, between 1993 and 2018, the average annual growth of Korea's GDP $\left(z_{i t}\right)$ was $6.02 \%$; using the elasticities of the model results, this implies that the maximum growth rate of Mexico $(y * i t)$ would be equal to $7.69 \%$. According to the data presented above, the growth rate of Mexican GDP in purchasing power parity dollars in the same period was $4.89 \%$, then, the increase in trade relations with South Korea would allow Mexico to accelerate its growth rate without facing constraints in the balance of payments. This does not generally occur in the country's foreign trade; in fact, it has been found that the income elasticity of imports is higher than the income 
elasticity of exports. With a trade agreement, Mexico would not only consolidate its growth path in the long term, but would also diversify its international trade, as most countries currently do.

In order to satisfy Equation (11), the effect of relative prices would need to be weak, and trade policy would need to be stable. In theory, this could be achieved precisely through the operation of an FTA between both countries and would bring about long-term equilibrium. In practice, however, that is not the current situation in their trade relationship. Mexico's maximum growth rate could be higher according to Equation (7) and could even reach 10\% if Mexican foreign trade would solely concentrate with Korea. Obviously, this is not a feasible situation, given the pattern of commercial dependence of Mexico with the United States; however, it does show that strengthening the commercial relationship with South Korea would accelerate Mexico's growth rate and would not imply external restriction problems.

There is great potential for South Korea and Mexico to deepen their commercial relationship and expand their investment flows. The constitution of an FTA between these countries would solidify their efforts in promoting the Asia-Pacific Economic Cooperation (APEC), where Mexico has been a member since 1993, and would represent a step towards an Asia Pacific Free Trade Agreement (FTAAP), which has been an aspiration of APEC throughout its history [64].

\section{Conclusions}

Trade agreements undertaken in Mexico since the 1980s have not led to sustained economic growth for the country. In the context of the recent COVID-19 pandemic, the current Mexican trade model has revealed its shortcomings, and has been greatly affected by its high dependency on the United States economy. For these reasons, it is necessary to refocus international trade policy in Mexico, and we find that one of the most attractive markets to this end is South Korea.

The results of the tests we have carried out in this study show that Mexico and South Korea have a high degree of trade complementarity and that their trade relationship has strengthened in the past few decades. Therefore, achieving a free trade agreement (FTA) with South Korea would undoubtedly allow Mexico to diversify both its exports and imports.

As a country that lives off international trade, South Korea is also compelled to diversify its export destinations. The recent slowdown in the Chinese economy-caused by COVID-19-induced a reduction in Korean exports, since the country maintains a growing dependence on the Chinese market, due to its links in global value chains.

Like Mexico, South Korea has sought for a couple of decades the expansion of international trade through FTA. Latin America has positioned itself as a highly attractive market for the Asian country and Mexico has become a main destination for Korean investment and exports. The current crisis and recession in the leading markets of the world increases the importance of emerging markets, such as Latin America, especially Mexico, due to its complementarity with the Korean economy.

In addition to trade complementarity, South Korea and Mexico have established a long-term equilibrium relationship, under which there are no trade restrictions on growth for Mexico, contrary to its trade relations with the United States. For all of these reasons, we can establish that a broader bilateral trade relationship would be highly beneficial to the aspirations for trade diversification of both countries.

It is worth noting that we did not engage with trade performance in specific sectors of any country in this work; it would be advisable to extend the analysis of trade complementarity to identify which could be the most benefited products under a given FTA. In the same manner, we did not discuss the regional dimension of the effects that said agreement could have; this would be relevant considering that a greater commercial relationship with Korea could drive a relocation of economic activity in Mexico, as it happened with NAFTA. Therefore, it would also be desirable to broaden the analysis at a sub-regional level. 
Author Contributions: L.Q.-R., N.K.M., R.A.-R. and J.Á.-G. contributed equally to this work. All authors wrote, reviewed and commented on the manuscript. All authors have read and agreed to the published version of the manuscript.

Funding: This work was supported by Hankuk University of Foreign Studies research fund of 2019. This work was supported by the Ministry of Education of Republic of Korea and the National Research Foundation of Korea (NRF-2019S1A6A3A02058027).

Acknowledgments: The authors would like to thank Alejandra S. Ortiz-Garcia for excellent translation services (ales.ortizg@gmail.com).

Conflicts of Interest: The authors declare no conflict of interest.

\section{Appendix A}

Table A1. Database.

\begin{tabular}{|c|c|c|c|c|c|}
\hline Year & $\mathrm{XPPP}^{1}$ & MPPP $^{2}$ & GDPKPPP $^{3}$ & GDPMXPPP ${ }^{4}$ & $\mathrm{TCR}^{5}$ \\
\hline 1993 & $41,092.63$ & $1,041,945.67$ & $480,622,075.99$ & $758,247,409.11$ & 3.12 \\
\hline 1994 & $58,276.73$ & $1,104,152.10$ & $536,076,762.05$ & $812,704,221.64$ & 3.39 \\
\hline 1995 & $190,748.58$ & $831,262.06$ & $599,698,967.06$ & $777,544,178.69$ & 6.43 \\
\hline 1996 & $398,767.52$ & $1,163,856.42$ & $657,057,761.63$ & $845,410,743.58$ & 7.60 \\
\hline 1997 & $121,633.24$ & $2,011,883.69$ & $707,970,980.80$ & $918,870,686.64$ & 7.92 \\
\hline 1998 & $126,888.45$ & $3,296,823.76$ & $676,768,831.32$ & $977,196,844.45$ & 9.15 \\
\hline 1999 & $255,082.82$ & $4,379,196.02$ & $764,178,264.90$ & $1,018,601,794.03$ & 9.55 \\
\hline 2000 & $277,647.60$ & $5,585,471.80$ & $850,045,546.52$ & $1,096,780,829.25$ & 9.46 \\
\hline 2001 & $432,315.02$ & $6,015,974.92$ & $908,001,494.02$ & $1,116,305,299.60$ & 9.34 \\
\hline 2002 & $238,560.20$ & $6,354,755.94$ & $989,824,399.77$ & $1,137,595,954.62$ & 9.67 \\
\hline 2003 & $294,487.13$ & $6,187,462.08$ & $1,023,783,139.57$ & $1,183,622,615.61$ & 10.79 \\
\hline 2004 & $353,550.14$ & $7,537,845.20$ & $1,102,859,681.00$ & $1,263,142,572.21$ & 11.29 \\
\hline 2005 & $369,797.20$ & $8,432,493.32$ & $1,165,894,061.00$ & $1,341,775,400.31$ & 10.89 \\
\hline 2006 & $696,611.21$ & $13,129,547.12$ & $1,250,723,763.68$ & $1,485,209,697.97$ & 10.90 \\
\hline 2007 & $1,008,565.68$ & $15,218,167.29$ & $1,354,489,639.00$ & $1,560,053,813.91$ & 10.93 \\
\hline 2008 & $801,029.51$ & $18,973,342.15$ & $1,405,710,904.23$ & $1,653,898,166.71$ & 11.14 \\
\hline 2009 & $907,271.23$ & $16,950,274.92$ & $1,396,654,746.28$ & $1,637,276,799.54$ & 13.50 \\
\hline 2010 & $1,528,774.94$ & $17,502,207.34$ & $1,504,724,405.18$ & $1,741,129,416.22$ & 12.63 \\
\hline 2011 & $2,463,892.58$ & $17,720,196.91$ & $1,559,446,833.87$ & $1,911,319,122.23$ & 12.43 \\
\hline 2012 & $2,893,384.15$ & $17,579,163.44$ & $1,611,272,914.64$ & $2,012,767,821.89$ & 13.17 \\
\hline 2013 & $2,470,911.47$ & $16,998,189.57$ & $1,644,777,306.03$ & $2,064,490,858.17$ & 12.77 \\
\hline 2014 & $3,349,635.43$ & $16,631,896.64$ & $1,704,457,641.24$ & $2,171,926,769.95$ & 13.30 \\
\hline 2015 & $5,359,231.33$ & $19,287,230.38$ & $1,824,331,972.26$ & $2,228,163,971.08$ & 15.88 \\
\hline 2016 & $5,388,267.93$ & $18,313,382.21$ & $1,903,410,732.09$ & $2,316,590,729.75$ & 18.69 \\
\hline 2017 & $7,176,918.30$ & $20,567,793.21$ & $1,998,129,726.32$ & $2,423,665,719.22$ & 18.91 \\
\hline 2018 & $8,503,605.83$ & $21,393,708.33$ & $2,071,181,809.85$ & $2,504,211,474.50$ & 19.24 \\
\hline
\end{tabular}

${ }^{1}$ XPPP: Exports from Mexico to South Korea in purchasing parity power dollars. ${ }^{2}$ MPPP: Korean imports from Mexico in purchasing parity power dollars. ${ }^{3}$ GDPKPPP: South Korean GDP in purchasing parity power dollars. ${ }^{4}$ GDPMXPP: Mexican GDP in purchasing parity power dollars. ${ }^{5} \mathrm{TCR}$ : Real exchange rate from Mexican pesos to dollars. Source: The World Bank [58], Indicators. 
Table A2. Descriptive statistics of logarithmic transformations of data in Table A1.

\begin{tabular}{lrrrrr}
\hline \multicolumn{1}{c}{ Statistic } & \multicolumn{1}{c}{ LXPPP } & \multicolumn{1}{c}{ LMPPP } & LGDPK & LGDPMX & \multicolumn{1}{c}{ LTCR } \\
\hline Mean & 13.44 & 15.82 & 20.84 & 21.06 & 4.69 \\
\hline Median & 13.22 & 16.17 & 20.91 & 21.07 & 4.66 \\
\hline Maximum & 15.96 & 16.88 & 21.45 & 21.64 & 5.07 \\
\hline Minimum & 10.62 & 13.63 & 19.99 & 20.45 & 4.42 \\
\hline Std. Dev. & 1.49 & 1.07 & 0.43 & 0.38 & 0.14 \\
\hline Skewness & 0.04 & -0.85 & -0.37 & -0.05 & 0.57 \\
\hline Kurtosis & 2.08 & 2.39 & 1.94 & 1.71 & 3.91 \\
\hline Observations & 26.00 & 26.00 & 26.00 & 26.00 & 26.00 \\
\hline Mean & 13.44 & 15.82 & 20.84 & 21.06 & 4.69 \\
\hline
\end{tabular}

Table A3. Correlation Matrix of logarithmic transformations of data in Table A1.

\begin{tabular}{lrrrrr}
\hline \multicolumn{1}{c}{ Variable } & \multicolumn{1}{c}{ LXPPP } & \multicolumn{1}{c}{ LMPPP } & LGDPK & LGDPMX & \multicolumn{1}{c}{ LTCR } \\
\hline LXPPP & 1.000 & 0.848 & 0.949 & 0.958 & 0.225 \\
\hline LMPPP & 0.848 & 1.000 & 0.957 & 0.936 & -0.176 \\
\hline LPIBKP & 0.949 & 0.957 & 1.000 & 0.987 & 0.027 \\
\hline LPIBMXP & 0.958 & 0.936 & 0.987 & 1.000 & 0.055 \\
\hline LTCR & 0.225 & -0.176 & 0.027 & 0.055 & 1.000 \\
\hline
\end{tabular}

\section{References}

1. López, J. (Ed.) El Proceso de Ajuste de la Economía Mexicana 1982-1992. In Mexico, La Nueva Macroeconomía; Nuevo Horizonte Editores: Mexico City, Mexico, 1995.

2. Blecker, R.A. The Mexican and US Economies After Twenty Years of NAFTA. Int. J. Polit. Econ. 2015, 43, 5-26.

3. Martínez, F.; Quintana, L.; Valencia, R. Análisis Macroeconómico de los Efectos de la Liberalización Financiera y Comercial sobre el Crecimiento Económico de Mexico, 1988-2011. Perf. Latinoam. 2015, 23, 79-104. [CrossRef]

4. Quintana, L.; Andrés-Rosales, R.; Mun, N. Crecimiento y Desarrollo Regional de Mexico y Corea del Sur: Un Análisis Comparativo de las Leyes de Kaldor. Investig. Econ. 2013, 72, 83-110. [CrossRef]

5. Bahmani-Oskooee, M.; Niroomand, F. Openness and economic growth: An empirical investigation. Appl. Econ. Lett. 1999, 6, 557-561. [CrossRef]

6. Frankel, J.A.; Romer, D. Does trade cause growth? Am. Econ. Rev. 1999, 89, 379-399. [CrossRef]

7. Karras, G. Trade openness and economic growth: Can we estimate the precise effect? App. Econ. Int. Dev. 2003, 3, 7-24.

8. Yanikkaya, H. Trade openness and economic growth: A cross-country empirical investigation. J. Dev. Econ. 2003, 72, 57-89. [CrossRef]

9. Dollar, D.; Kraay, A. Trade. Growth and Poverty. Econ. J. 2004, 114, 22-49. [CrossRef]

10. Wang, C.; Liu, X.; Wei, Y. Impact of openness on growth in different country groups. The World Econ. 2004, 27, 567-585. [CrossRef]

11. Rassekh, F. Is international trade more beneficial to lower income economies? An empirical inquiry. Rev. Dev. Econ. 2004, 11, 159-169. [CrossRef]

12. Freund, C.; Bolaky, B. Trade, regulations, and income. J. Dev. Econ. 2008, 87, 309-321. [CrossRef]

13. Chang, R.; Kaltani, L.; Loayza, N.V. Openness can be good for growth: The role of policy complementarities. J. Dev. Econ. 2009, 90, 33-49. [CrossRef]

14. Kim, D.-H.; Lin, S. Trade and growth at different stages of economic development. J. Dev. Stud. 2009, 45, 1211-1224. [CrossRef] 
15. Dufrenot, G.; Mignon, V.; Tsangarides, C. The trade-growth nexus in the developing countries: A quantile regression approach. Rev. World Econ. 2010, 146, 731-761. [CrossRef]

16. Das, A.; Paul, B.P. Openness and growth in emerging Asian economies: Evidence from GMM estimations of a dynamic panel. Econ. Bull. 2011, 31, 2219-2228.

17. Kim, D.-H.; Lin, S.-C.; Suen, Y.B. Nonlinearity between trade openness and economic development. Rev. Dev. Econ. 2011, 15, 279-292. [CrossRef]

18. Marelli, E.; Signorelli, M. China and India: Openness, trade and effects on economic growth. Eur. J. Comp. Econ. 2011, 8, 129-154.

19. Shahbaz, M. Does trade openness affect long-run growth? Cointegration, causality and forecast error variance decomposition tests for Pakistan. Econ. Model. 2012, 29, 2325-2339. [CrossRef]

20. Nowbutsing, B.M. The impact of openness on economic growth: Case of Indian Ocean rim countries. J. Econ. Dev. Stud. 2014, 2, 407-427.

21. Zarra-Nezhad, M.; Hosseinpour, F.; Arman, S.A. Trade-growth nexus in developing and developed countries: An application of extreme bounds analysis. Asian Econ. Financ. Rev. 2014, 4, 915-929.

22. Vamvakidis, A. How robust is the growth-openness connection: Historical evidence. J. Econ. Growth 2002, 7, 57-80. [CrossRef]

23. Afzal, M.; Hussain, I. Export-led growth hypothesis: Evidence from Pakistan. J. Quant. Econ. 2010, 8, 130-147.

24. Ulaşan, B. Trade openness and economic growth: Panel evidence. Appl. Econ. Lett. 2015, 22, 163-167. [CrossRef]

25. Fenira, M. Trade openness and growth in developing countries: An analysis of the relationship after comparing trade indicators. Asian Econ. Financ. Rev. 2015, 5, 468-482. [CrossRef]

26. Rigobon, R.; Rodrik, D. Rule of law, democracy, openness, and income: Estimating the interrelationships. Econ. Transit. 2005, 13, 533-564. [CrossRef]

27. Bhagwati, J. The FTAA is not a Free Trade. In Annual World Bank Conference on Development in Latin America and the Caribbean, 1997: Trade, Towards Open Regionalism; The World Bank: Washington, DC, USA, 1998; pp. 13-19.

28. Viner, J. The Customs Union Issue; Carnegie Endowment for International Peace: Washington, DC, USA, 1950.

29. Lipsey, R.G. La Teoría de las Uniones Aduaneras. Una Reseña General. In Integración Económica; Andic, S., Teitel, S., Eds.; Fondo de Cultura Económica: Mexico, Mexico, 1977; p. 1201345.

30. Johnson, H. Optimal Trade Intervention in the Presence of Domestic Distortions. In Trade Growth and the Balance of Payments; Caves, R.E., Johnson, H., Kenen, P.B., Eds.; Rand McNally: Chicago, IL, USA, 1965; pp. 3-34.

31. Kehoe, T.J. An Evaluation of the Performance of Applied General Equilibrium Models of the Impact of NAFTA; Federal Reserve Bank of Minneapolis Working Paper 320; Federal Reserve Bank of Minneapolis: Minneapolis, MN, USA, 2003.

32. Krugman, P. Rethinking International Trade. Bus. Econ. 1988, 23, 7-12.

33. Krugman, P. Regionalism Versus Multilateralism: Analytical Notes. In New Dimensions in Regional Integration; De Melo, J., Ed.; Cambridge University Press: Cambridge, UK, 1993; pp. 58-79.

34. North, D. Instituciones, Cambio Institucional y Desempeño Económico; Fondo de Cultura Económica: Mexico, Mexico, 1995.

35. Mattli, W. The Logic of Regional Integration: Europe and Beyond; Cambridge University Press: London, UK, 1999.

36. Summers, L. Regionalism and the World Trading System. In Symposium on Policy Implications of Trade and Currency Zones; Federal Reserve, Bank of Kansas City: Kansas City, MO, USA, 1991.

37. Wannacott, P.; Lutz, M. Is there a case for free trade areas? In Free Trade areas and U.S. Trade Policy; Schott, J.J., Ed.; Institute for International Economics Washington: Washington, DC, USA, 1989; pp. 59-84.

38. Chandran, S. Trade Complementarity and Similarity between India and Asean Countries in the Context of the RTA; VVM ShreeDamodar Collage of Commerce and Economics: Margao, India, 2010.

39. Thirlwall, A.P. The Balance of Payments Constraint as an Explanation of the International Growth Rate Differences. Banc. Nazionale Lavoro Q. Rev. 1979, 32, 45-53.

40. Alonso, J.A.; Garcimartín, C. Apertura Comercial y Estrategia de Desarrollo; Universidad Complutense de Madrid, Instituto Complutense de Estudios Internacionales: Madrid, Spain, 2005.

41. Parikh, A. Relationship Between Trade Liberalization, Growth, and Balance of Payments in Developing Countries: An Econometric Study. Int. Trade J. 2006, 20, 429-467. [CrossRef] 
42. Atesoglu, H.S. Balance-Of-Payments-Constrained Growth: Evidence from the United States. J. Post Keynes. Econ. 1993, 15, 507-514. [CrossRef]

43. Bajo Rubio, O.; Díaz Roldán, M.C. Does the Balance of Payments Constrain Economic Growth?: Some Evidence for the New EU Members; Papeles de trabajo del Instituto de Estudios Fiscales, Serie Economía; Instituto de Estudios Fiscales: Madrid, Spain, 2009; pp. 3-18.

44. Ghani, G.M. Balance of Payments Constrained Growth Model: An Examination of Thirlwall's Hypothesis Using Mccombie's Individual Country Method. Appl. Econ. Lett. 2006, 13, 763-768. [CrossRef]

45. Landesmann, M.; Pöchl, J. Balance-Of-Payments Constrained Growth in Central and Eastern Europe and Scenarios of East-West Integration. Russ. East Eur. Financ. Trade 1996, 32, 30-84.

46. Moreno-Brid, J.C. Mexico's Economic Growth and the Balance of Payments Constraint: A cointegration analysis. Int. Rev. Appl. Econ. 1999, 13, 149-159. [CrossRef]

47. Pacheco-López, P. The Impact of Trade Liberalisation on Exports, Imports, the Balance of Payments and Growth: The Case of Mexico. J. Post Keynes. Econ. 2005, 27, 595-619.

48. Pacheco-López, P.; Thirlwall, A.P. Trade Liberalisation, the Balance of Payments and Growth in Latin America. Int. Rev. Appl. Econ. 2007, 21, 469-490. [CrossRef]

49. Schiff, M. Will the Real "Natural Trading Partner" Please Stand up? Development Research Department, World Bank: Washington, DC, USA, 1999.

50. Thirlwall, A.P. Reflections on the Concept of Balance-of-Payments-Constrained Growth. J. Post Keynes. Econ. 1997, 19, 377-385. [CrossRef]

51. Kaldor, N. A Model of Economic Growth. Econ. J. 1957, 67, 591-624. [CrossRef]

52. Mejia Reyes, P.; Eduardo Gutierrez Alva, E.; Farias Silva, C.A. The Synchronization of The Economic Cycles of Mexico and the United States. Investig. Econ. 2006, 65, 15-45.

53. Mendoza, M.; Quintana, L.; Valdivia, M.; Salas, C. Impactos Macroeconómicos del COVID-19 en la Economía Mexicana. Laboratorio de Análisis Económico Regional UNAM 2020. Available online: https: //labregional-unam.blogspot.com/2020/03/impactos-macroeconomicos-potenciales-en.html (accessed on 18 March 2020).

54. SaKong, I.; Koh, Y. La Economía Coreana: Seis Décadas de Crecimiento y Desarrollo; ECLAC: Santiago, Chile, 2018.

55. BANXICO. Balance of Payments' Indicators. Economic Information System (SIE). México. Available online: https:/www.banxico.org.mx/SieInternet/consultarDirectorioInternetAction.do?accion= consultarCuadroAnalitico\&idCuadro=CA126\&sector=12\&locale=en (accessed on 3 June 2019).

56. COMTRADE Database. UN United Nations Commodity Trade Statistics Database, Comtrade Database. United Nations Statistics Division. Available online: https://comtrade.un.org/ (accessed on 3 June 2019).

57. SIGCI-ECLAC. Interactive Graphic System for International Trade Data. United Nations Economic Commission for Latin America and The Caribbean (UN ECLAC): Santiago, Chile. Available online: http://www.eclac.org/comercio/SIGCI/ (accessed on 3 June 2019).

58. Mun, N.; Quintana, L. El Comercio de México con Corea Del Sur en el Marco del TLCAN. Revista de Comercio Exterior 2003, 53, 1148-1154.

59. McCombie, J.S.L.; Thirlwall, A.P. Economic Growth and the Balance-of-Payments Constraint; Palgrave Macmillan: London, UK, 1994.

60. Quintana, L.; Mendoza, M. Econometría Básica, Modelos y Aplicaciones a la Economía Mexicana; Plaza y Valdés: Mexico, Mexico, 2007.

61. The World Bank. The World Bank. DataBank. World Development Indicators; World Bank: Washington, DC, USA; Available online: https://databank.worldbank.org/reports.aspx?source=2\&country=USA (accessed on 3 June 2019).

62. Im, K.S.; Pesaran, M.; Shin, Y. Testing for Unit Roots in Heterogeneous Panels. J. Econ. 2003, 113, 53-74. [CrossRef]

63. Park, J.Y. Canonical Cointegrating Regressions. Econometrica 1992, 60, 119-143. [CrossRef]

64. Palacios, J.J. Liberalising Trans-Pacific Trade: An Ex-ante Assessment of the Mexico-South Korea FTA-to-be. Korea World Econ. 2012, 13, 141-174.

(C) 2020 by the authors. Licensee MDPI, Basel, Switzerland. This article is an open access article distributed under the terms and conditions of the Creative Commons Attribution (CC BY) license (http://creativecommons.org/licenses/by/4.0/). 